Volume 11| Issue 3

July 2020

\title{
Education in the Post-Pandemic Era: Indigenous Children and Youth
}

Lorenzo Cherubini

BrockUniversity, Canada, lorenzo.cherubini@brocku.ca

Recommended Citation

Cherubini, L. (2020). Education in the post-pandemic era: Indigenous children and youth [Editorial]. The International Indigenous Policy Journal, 11(3). https://doi.org/10.18584/iipj.2020.11.3.10679 


\title{
Education in the Post-Pandemic Era: Indigenous Children and Youth
}

\begin{abstract}
The COVID-19 pandemic crisis resulted in more than 100 countries legislating school closures in March 2020. In response, provincial ministries and their respective publicly funded school boards have implemented online learning platforms to avoid disruptions to student learning. For students already ostracized in public education, online learning may serve to further embed them in the proverbial margins. This editorial speaks to the urgency for educators at all levels to prepare for the potentially devastating outcomes on Indigenous student learning and progress in post-pandemic public schools and classrooms. The preparation for these realities has to be both immediate and retrospective given the complexities of these unique circumstances that have created interwoven layers of marginalization for Indigenous students.
\end{abstract}

\section{Keywords}

Indigenous education, Indigenous student learning, post-pandemic, COVID-19, digital divide, online learning

\section{Creative Commons License (a) $\mathbb{\oplus \Theta \Theta}$}

This work is licensed under a Creative Commons Attribution-Noncommercial-No Derivative Works 4.0License. 


\section{Education in the Post-Pandemic Era: Indigenous Children and Youth}

The COVID-19 pandemic crisis resulted in more than 100 countries legislating school closures in March 2020, significantly altering the education of over 860 million children and youth globally (Viner et al., 2020). Across Canada, provincial ministries of education enacted landmark policy decisions to close publicly funded schools, and Ontario was among the first jurisdictions in the industrialized world to issue a Ministerial Order to close schools in an effort to contain the spread of the virus (Ontario Ministry of Education, 2020). In response, provincial ministries and their respective publicly funded school boards have implemented variations of online learning platforms to avoid major disruptions to students' learning and progress. Teachers are required to deliver online learning modules and/or virtual lessons in a timely and grade-appropriate fashion. Teachers also will continue to assess and evaluate student progress in accordance with provincial policies. In these unprecedented times of social distancing, online learning appears to be the only recourse in lieu of postponing the education for the just below five million elementary and secondary school students across Canada (Duffin, 2020).

For some students, however, virtual learning is not conducive to learning (Szabo et al., 2020). Moreover, for children and youths who already feel ostracized in public education, online learning may serve to further embed them in the proverbial margins. This may be the case for many Indigenous students across the country who experience a range of educational disparities that are compounded by the lack of infrastructure and support related to the necessary technology to sustain virtual learning (Friesen \& Krauth, 2010; Steeves et al., 2010). It should be noted that public education in Canada is governed by each respective province and territory, with the exception of First Nations education on reserve that receives funding from the federal government to build and operate education infrastructure. Indigenous students are disproportionately affected by issues related to higher rates of poverty, substance abuse, and health-related issues (Cumming \& Draper Rodriguez, 2019; Richards et al., 2010). Further contributing to marginalization is the fact that many Indigenous students attend schools that do not include culturally informed curriculum and pedagogical practices (Cherubini, 2014; Philpott \& Nesbit, 2010) and may have experienced the residual consequences of the residential school era (Brade et al., 2003). Indigenous students also have higher transient school enrolment and attendance rates compared to Indigenous students, contributing to their comparably lower secondary school graduation rates (Julien, 2016; Puchala et al., 2010). ${ }^{1}$

Consider too that the earnings gap between Indigenous and non-Indigenous males is cited as ranging from $20 \%$ to $50 \%$, with an even wider range for those living on reserve (Feir, 2013). The employment rate among Indigenous Peoples is nearly $25 \%$ lower than for non-Indigenous people in Canada. They also have, on average, lower levels of technology skills, due in part to the systemic barriers related to accessing technology (Hu et al., 2019). For students living in isolated Indigenous communities, the barriers to broadband internet access, as well as other inequities related to social exclusion, are heightened (Subhan et al., 2020). It is interesting, though, that Indigenous students living in many of these remote Indigenous communities are privy to the traditional land-based teachings and activities of Elders (Oskineegish, 2014). Traditional Knowledge and land-based teaching practices may have an even

\footnotetext{
${ }^{1}$ It should be noted that Indigenous people represent over $4 \%$ of the population in Canada. This population has seen a $20 \%$ increase between 2006 and 2011, compared to a 5\% growth rate among non-Indigenous Canadians (Gordon \& White, 2014; Statistics Canada, 2016).
} 
greater currency given the closure of schools and places of social gathering. For some, the violations of Treaties and Land Agreements by colonizers, assimilation policies that included removing children from Indigenous families, and the indirect repercussions of education policies that discriminate against Indigenous learners "locates disadvantage as an inherent and self-evident part of Aboriginality" (Walter, 2009, p. 2; see also Brown, 2019). In the current online learning environments engendered by the global pandemic, the aforementioned inequities experienced by some Indigenous students complicate their already marginalized experiences.

This editorial, consequently, speaks to the urgency for education ministries, board and school administrators, and classroom teachers to prepare for the potentially devastating outcomes on some Indigenous students' learning and progress in post-pandemic public schools and classrooms. The preparation for these realities has to be both immediate and retrospective given the complexities of these unique circumstances that have created interwoven layers of marginalization for Indigenous children and youth. When schools return to normal, educators will have to account for the varying levels of discontinuity of many learners. Indigenous students, already in the margins of education policies and practices, may be situated in significantly more complex and nuanced post-pandemic realities.

\section{Context}

Although Canada is ranked quite favourably among Organisation for Economic Co-operation and Development (OECD) member countries in terms of delivering an equitable education system, there are educational gaps between higher and lower SES students (Castejón \& Zancajo, 2015; Chmielewski \& Reardon, 2016). Students from higher SES backgrounds benefit more from the support networks available to them and from greater access to information and services (Anisef et al., 2010). The educational disparities of Indigenous students are especially marked by these SES factors (Mayor \& Suarez, 2019). While Indigenous people certainly are not a homogenous population, they "do share a common experience with colonization and racialization” (St. Denis, 2007, p. 1087). According to Schick (2014), Indigenous Peoples are historically situated as "other" in the social and political contexts of White settlers, which contributes to (and fosters) the despairing socio-economic inequities between Indigenous Peoples and non-Indigenous people (Loppie et al., 2014).

Moreover, the meaningful inclusion of Indigenous epistemologies in classrooms to honour Indigenous students' identities is uncommon (Cherubini, 2015; Miller, 2018), as is the use of Indigenous Traditional Knowledges to strengthen students' self-esteem (McDonald, 2011). Instead, the hidden curriculum of public schools - representing mainstream White traditions and values - underscores the significance of Eurocentric knowledge paradigms and student behaviours that are rewarded and celebrated (Rahman, 2013). Students' success in education is largely dependent upon their assuming an identity that may not be their own, as well as their ability and willingness to conform to mainstream schools' predetermined values and behaviour (Kentli, 2009). As Watego (2005) suggested, the sociocultural norms related to compliance with mainstream public schools' expectations are not necessarily familiar to some Indigenous students and communities. Often, Indigenous families and communities are perceived inauspiciously by mainstream educators who attribute Indigenous persons' seeming lack of involvement to disinterest (Lea et al., 2011), resulting in fewer opportunities for Indigenous students to acknowledge their unique epistemologies and worldviews, which ultimately contributes to feelings of inadequacy and disengagement from formal education (Julien, 2016). This may explain the growth of 
Cherubini: Education in the Post-Pandemic Era

alternative education programs tailored specifically for Indigenous students who have not fared well in mainstream schools. ${ }^{2}$ In Ontario, as an example of one Canadian province, Ontario Native Friendship Centres oversee 11 different alternative school settings for Indigenous youths studying in nontraditional classrooms and earning secondary school credits.

Quite clear in all of the above context is that for some Indigenous students' success in public education is erratic and elusive. Their relationship to mainstream teachers and school policies and practices is often incongruous with the dominant values espoused by the hidden curriculum of schools; instead, theirs is a plurality of social, cultural, and traditional interpretations that in many instances is in stark contrast to Eurocentric paradigms of teaching and learning. As a function of these differences, many Indigenous students feel marginalized in mainstream public schools and classrooms and cannot distill their unique identities in these socio-political learning climates.

\section{Discussion}

The current online delivery models designed to curtail the COVID-19 outbreak may serve to position some Indigenous students in even more interwoven layers of marginalization in post-pandemic schools and classrooms. Consider, first, how the online platforms adopted across the Canada may disadvantage Indigenous epistemologies based on holistic and communal learning. For Indigenous students already struggling with attendance issues due to their disengagement in public education, the demands of online learning certainly are not beneficial. For those students living in poverty who depend on schools for nourishment and health-related services, virtual education essentially will be useless. Furthermore, the achievement gap between Indigenous and non-Indigenous students may be widening significantly during the response to "flatten the curve." Indigenous students may return to post-pandemic classrooms with an even narrower focus on learning and with far less capital to identify and build on their knowledge.

This is not to ignore the fact that some Indigenous students are prepared to manage the demands of online instruction and are benefitting from the virtual learning. These are the students that have gained from various education policy directives that have commissioned principals, teachers, and other educators to account for Indigenous students' diverse learning needs and preferences (Cherubini, 2014). These students have been successful in learning environments that have appealed to their unique identities as Indigenous Peoples (Toulouse, 2013). Moreover, since the release of the TRC (2015b) final report, there has been a renewed focus on fostering harmonious relationships between Indigenous Peoples and non-Indigenous peoples in a spirit of respect and relationality (Cutrara, 2018). The TRC (2015a) report's Call to Action \#62 points to the significance of implementing culturally appropriate curriculum in $\mathrm{K}$ to 12 publicly funded schools to promote intercultural understandings that reflect Indigenous students' epistemic and cultural realities.

However, one cannot help but wonder if some of the progress made in educational outcomes and in Indigenizing education at both the federal and provincial levels will be curtailed and/or eliminated in the wake of the costs incurred by all levels of government in response to the pandemic and in light of the

\footnotetext{
${ }^{2}$ According to Winzer's (1997) research spanning the 1980s and 1990s, nearly $25 \%$ of students in Canada who were identified as needing specialized help attended alternative education placements.
}

Published by Scholarship@Western, 2020 
impending recovery measures. We need to look no further than the Ontario (Canada) Conservative government's decision in 2018, despite the TRC Calls to Action and the Ontario Ministry of Education's (2007) declaration of Indigenous education as a priority, to cancel the curriculum writing sessions meant to infuse Indigenous content and history into the school curriculum (Benzie, 2018). The decision to cancel the project that included Elders and Indigenous educators from across the province was explained as a cost-saving measure. Post-pandemic education systems may be well-served to prepare themselves for mitigating the outcomes of similar decisions.

It is imperative, too, to consider how the deficit discourse that typically frames Indigenous students and communities in mainstream schools will be accentuated if indeed the learning gaps between Indigenous and non-Indigenous students are even more pronounced when schools reopen. This may contribute to further racist experiences for Indigenous students (see Bodkin-Andrews \& Carlson, 2016) and thus result in an increase in inequitable practices (Ferguson, 2003). Indigenous students may be exposed to an even deeper layer of stereotype threat, described as students' "perception of their teacher's negative opinion of their potential [to] create enough emotional dissonance to be detrimental towards their achievement or relationship with the school" (Riley \& Pidgeon, 2019, p. 127; see also Hynds et al., 2017). Such a threat can be an affront to Indigenous students already feeling marginalized and may contribute to their leaving school altogether (Dharan et al., 2012). Educators may have to reflect on and expand their knowledge of Indigenous students' realities in pre- and post-pandemic circumstances, and plan for shared interactions with Indigenous students, families, and communities. Parental involvement contributes to student achievement, just as community collaborations with health and social service agencies enhance student well-being (Phillips et al., 2011). By inviting Indigenous parents and communities to plan for post-pandemic realities, teachers can learn how to implement culturally appropriate instruction that complements the worldviews students learn at home (Pushor \& Murphy, 2004). It also creates a new way in which Indigenous parents can be actively involved in their children's progress and development in school. In this way, teachers may perceive themselves as working alongside parents in meaningful acts of engagement (Pushor, 2012). Educators can learn more about the interdependence of child rearing shared by the extended family to support Indigenous children in the development of their education (Irvine, 2009). By considering thoughtfully the disruptions and distortions of Indigenous students' experiences, teachers will be better able to plan individualized and consistent strategies to (re)engage such students into more inclusive and inviting classrooms. The onus will be on educators at all levels to develop culturally appropriate and informed courses of action in the context of the interwoven layers of marginalization that some Indigenous students may bring back to post-pandemic classrooms.

There is also the issue of the digital divide that marginalizes some students. Indigenous communities have petitioned for greater broadband connectivity and integrated information communication technology and identified them as essential for the delivery of social and education services; further, Indigenous communities have cited the high costs of satellite technology to connect northern and remote locations across Canada (Assembly of First Nations, 2016). Despite an investment of over $\$ 500$ million dollars in 2016 by the Canadian federal government to extend broadband internet to remote communities, there is still a significant difference in service between urban and remote areas. In prepandemic times, the digital divide prevented students living in remote Indigenous communities from having equitable access as non-Indigenous students to services and connectivity (Ruimy, 2017). To facilitate the successful transition to online learning, the digital divide for some students has only 
widened. Indigenous students may not have access to the necessary hardware, technical support, or digital skills to successfully negotiate the demands of virtual classrooms (Resta \& Laferriere, 2015). Such demands may underscore the disparity between mainstream Canadians and Indigenous Peoples that already existed before the pandemic (Koncan, 2014). The lack of infrastructure, expensive technology, sparse support with technology, and the shortage of teachers with expertise in information technology contributes to the digital exclusion of some Indigenous students (Resta \& Laferriere, 2015). Educators will need to assess the extent to which students were able to connect and engage in their studies during the pandemic and have thoughtful plans for encompassing the wide range of learning outcomes across the digital divide.

For those Indigenous students attending alternative school settings, the complexities inherent in the tiers of marginalization that divide them from mainstream school systems are not any simpler. Indigenous students who have left mainstream schools were already divided from mainstream students (Thorne, 2017). If their learning progress has been stifled by online learning delivery models, a return to alternative school may further accentuate their sense of marginalization. One cannot help but wonder how these students will have fared emotionally with having their learning restricted even in alternative settings. The "at-risk" designation applied to students enrolled in alternative education placements already implies a sense of inferiority to mainstream students and contributes to their alienation (Julien, 2016). Educators need to examine and prepare for these students who may feel unsuccessful and unable to respond positively to the complicated and possibly confusing demands of the alternate school programs, which include students with a myriad of learning needs, styles, and preferences. Students are generally scheduled in a single cohort or classroom but are functioning at different levels. This makes programming complex for teachers (accounting and balancing these needs) and often means employing different pedagogical practices to meet the epistemic preferences and interests of these students. Teachers will have to create invitational learning environments that recognize the sense of dignity and worth of each student well before any implementation of instructional design. The layers of marginalization may underscore the exceptionally unfavourable circumstances experienced by some Indigenous learners.

\section{Conclusion}

Post-pandemic classrooms, in both mainstream and alternate school settings, will be very different for Indigenous students - especially those who were already feeling marginalized prior to the school closures. Educators at all levels, from ministry and First Nations policy makers to classroom teachers, are commissioned to take intelligent action to address Indigenous students' marginalization when the school bell rings again. Such action must account for the socio-economic realities that have historically contributed to Indigenous student underachievement in public schools, but also recognize how the online delivery models may have further privileged what in pre-pandemic conditions was already middle-class positioning (see Julien, 2016). Teachers must remain aware of the implications of deficit discourse as they prepare for what may be even larger learning gaps between Indigenous and nonIndigenous students, as one of many other inequities. It may be fruitful for mainstream educators to consult community Elders and Indigenous education leaders in their school communities for guidance on how to successfully address the layers of marginalization experienced by some Indigenous students. It may be fruitful for principals and teachers, in their post-pandemic planning, to inquire about Indigenous 
perspectives on land-based education (Simpson, 2014) as a means of furthering all students' knowledge about the importance of respecting the land and all living things. Datta (2018) refers to Marie Battiste's (Mi'kmaq from the Potlotek First Nation) point that:

Collective (Indigenous and non-Indigenous) move/transformation from Western to land-based learning does not reject Western science; however, Battiste challenges current uneven forms of education. Through the concept of move/ transformation, she seeks revitalization, which can bridge Indigenous and Western ways of thinking. (p. 52)

Given that many outdoor green spaces across the country are considered safer venues in the prevention of the spread of the virus, teachers can consider how land-based education may be a much better alternative to virtual learning. Place-based education utilizes hands-on and active learning techniques that may also be more conducive to student engagement than online learning (Calderon, 2014). In this way, Indigenous students' needs, ambitions, and abilities can complement teachers' planned learning goals. By being both retrospective and immediate in their collective and individual responses, educators can aim to represent and honour Indigenous student realities, identities, and epistemologies in postpandemic schools and classrooms across the country.

\section{References}

Anisef, P., Brown, R. S., Phythian, K., Sweet, R., \& Walters, D. (2010). Early school leaving among immigrants in Toronto secondary schools. Canadian Review of Sociology/Revue canadienne de sociologie, 47(2), 103-128. https://doi.org/10.1111/j.1755-618x.2010.01226.x

Assembly of First Nations. (2016). Annual General Assembly: E-community for First Nations: A national framework. https://www.ourcommons.ca/content/Committee/421/INDU/ WebDoc/WD9710635/421_INDU_reldoc_PDF/INDU_AssemblyOfFirstNations-e.pdf

Benzie, R. (2018, July 9). Ontario government moving forward with Indigenous lesson plan but cancels meetings to improve it. The Star. https://www.thestar.com/news/queenspark/2018/07/09/ ford-government-moving-forward-with-indigenous-lesson-plan-despite-austerity-push.html

Bodkin-Andrews, G., \& Carlson, B. (2016). The legacy of racism and Indigenous Australian identity within education. Race Ethnicity and Education, 19(4), 784-807. https://doi.org/ $\underline{10.1080 / 13613324.2014 .969224}$

Brade, C. R., Duncan, K. A., \& Sokal, L. (2003). The path to education in a Canadian Aboriginal context. Canadian Journal of Native Education, 27(2), 235-248.

Brown, L. (2019). Indigenous young people, disadvantage and the violence of settler colonial education policy and curriculum. Journal of Sociology, 55(1), 54-71. https://doi.org/10.1177/ $\underline{1440783318794295}$ 
Cherubini: Education in the Post-Pandemic Era

Calderon, D. (2014). Speaking back to Manifest Destinies: A land education-based approach to critical curriculum inquiry. Environmental Education Research, 20(1), 24-36. https://doi.org/10.1080/13504622.2013.865114

Castejón, A., \& Zancajo, A. (2015). Educational differentiation policies and the performance of disadvantaged students across OECD countries. European Educational Research Journal, 14(3-4), 222-239. https://doi.org/10.1177\%2F1474904115592489

Cherubini, L. (2014). Aboriginal student engagement and achievement: Educational practices and cultural sustainability. UBC Press.

Cherubini, L. (2015). Research in the context of sustainable dialogue: Aboriginal Peoples and educational policy in northern Ontario (Canada). International Journal of Information Technology \& Computer Science, 19(2), 13-25.

Chmielewski, A. K., \& Reardon, S. F. (2016). Patterns of cross-national variation in the association between income and academic achievement. AERA Open, 2(3), 1-27. https://doi.org/10.1177\%2F2332858416649593

Cumming, T., \& Draper Rodriguez, C. (2019). School success for at-risk students: A culturally responsive tiered approach. Routledge. https://doi.org/10.4324/9781315101996

Cutrara, S. (2018). The settler grammar of Canadian curriculum: Why historical thinking is unable to respond to the TRC's Calls to Action. Canadian Journal of Education, 41(1), 250-275.

Datta, R. (2018). Rethinking environmental science education from Indigenous knowledge perspectives: An experience with a Dene First Nation community. Environmental Education Research, 24(1), 50-66. https://doi.org/10.1080/13504622.2016.1219980

Dharan, V., Meyer, L., \& Mincher, N. (2012). At the receiving end: Are policies and practices working to keep students in high schools? New Zealand Annual Review of Education, 21, 119-141. https://doi.org/10.26686/nzaroe.v21i0.4045

Duffin, E. (2020, January 30). Education in Canada-Statistics \& facts. Statista. https://www.statista.com/topics/2863/education-in-canada/

Feir, D. (2013). Size, structure, and change: Exploring the sources of Aboriginal earnings gaps in 1995 and 2005. Canadian Public Policy/Analyse de politiques, 39(2), 309-34. https://doi.org/ $\underline{10.3138 / \text { cpp.39.2.309 }}$

Ferguson, R. F. (2003). Teachers' perceptions and expectations and the Black-White test score gap. Urban Education, 38(4), 460-507. https://doi.org/10.1177\%2F0042085903038004006 
Friesen, J., \& Krauth, B. (2010). Sorting, peers, and achievement of Aboriginal students in British Columbia. Canadian Journal of Economics/Revue canadienne d'économique, 43(4), 1273-1301. https://doi.org/10.1111/j.1540-5982.2010.01614.x

Gordon, C. E., \& White, J. P. (2014). Indigenous educational attainment in Canada. The International Indigenous Policy Journal, 5(3). https://doi.org/10.18584/iipj.2014.5.3.6

Hu, M., Daley, A., \& Warman, C. (2019). Literacy, numeracy, technology skill, and labour market outcomes among Indigenous Peoples in Canada. Canadian Public Policy, 45(1), 48-73. https://doi.org/10.3138/cpp.2017-068

Hynds, A., Averill, R., Hindle, R., \& Meyer, L. (2017). School expectations and student aspirations: The influence of schools and teachers on Indigenous secondary students. Ethnicities, 17(4), 546-573. https://doi.org/10.1177\%2F1468796816666590

Irvine, K. (2009). Supporting Aboriginal parents: Teachings for the future. National Collaborating Centre for Aboriginal Health.

Julien, R. (2016). Change now! A call to reform education for Canada's Aboriginal youth. The Canadian Journal of Native Studies, 26(2), 129-148.

Kentli, F. D. (2009). Comparison of the hidden curriculum theories. European Journal of Educational Studies, 1(2), 83-88.

Koncan, A. (2014). A literature survey of the global digital divide and Indigenous people [Doctoral dissertation, Athabasca University.] http://dtpr.lib.athabascau.ca/action/ download.php?filename=scis-07/open/alfonzkoncanEssay.pdf

Lea, T., Thompson, H., McRae-Williams, E., \& Wegner, A. (2011). Policy fuzz and fuzzy logic: Researching contemporary Indigenous education and parent-school engagement in north Australia. Journal of Education Policy, 26(3), 321-339. https://doi.org/10.1080/ $\underline{02680939.2010 .509813}$

Loppie, S., Reading, C., \& de Leeuw, S. (2014). Aboriginal experiences with racism and its impacts. National Collaborating Centre for Aboriginal Health. https://www.ccnsanccah.ca/publications/lists/publications/attachments/131/2014_07 09 fs 2426_racismpart 2 experiencesimpacts_en_web.pdf

Mayor, C., \& Suarez, E. B. (2019). A scoping review of the demographic and contextual factors in Canada's educational opportunity gaps. Canadian Journal of Education/Revue canadienne de l'éducation, 42(1), 42-87.

McDonald, R-A. J. (2011). First Nations languages and culture impacts on literacy and student achievement outcomes: Review of literature. Assembly of First Nations. https://www.afn.ca/ uploads/files/education/afn_languages and_culture and literacy_lit_review_april_5_2011. pdf 
Cherubini: Education in the Post-Pandemic Era

Miller, T. (2018). Measures of Indigenous achievement in Canada. Diaspora, Indigenous, and Minority Education, 12(4), 182-200. https://doi.org/10.1080/15595692.2018.1506436

Ministry of Education. (2007). Ontario First Nations, Métis, and Inuit education policy framework. http://www.edu.gov.on.ca/eng/aboriginal/fnmiFramework.pdf

Ontario Ministry of Education. (2020, March 24). Minister launches Phase 1 of Learn at Home. https://www.ontario.ca/page/letter-ontarios-parents-minister-education\#section-2

Oskineegish, M. (2014). Developing culturally responsive teaching practices in First Nations communities: Learning Anishnaabemowin and land-based teachings. Alberta Journal of Educational Research, 60(3), 508-521.

Phillips, S., Raham, H., Bredberg, E., \& Bredberg, E. (2011). Forging partnerships, opening doors: Community school case studies from Manitoba and Saskatchewan. Society for the Advancement of Excellence in Education. https://journalhosting.ucalgary.ca/index.php/ ajer/article/view/55942

Philpott, D., \& Nesbit, W. C. (2010). Approaching educational empowerment: Guidelines from a collaborative study with the Innu of Labrador. The International Indigenous Policy Journal, 1(1). https://doi.org/10.18584/iipj.2010.1.1.6

Puchala, C., Vu, L. T., \& Muhajarine, N. (2010). Neighbourhood ethnic diversity buffers school readiness impact in ESL children. Canadian Journal of Public Health/Revue canadienne de santée publique, 101(Suppl. 3), S13-S18.

Pushor, D. (2012). Tracing my research on parent engagement: Working to interrupt the story of school as protectorate. Action in Teacher Education (Association of Teacher Educators), 34(5/6), 464-479. https://doi.org/10.1080/01626620.2012.729474

Pushor, D., \& Murphy, B. (2004). Parent marginalization, marginalized parents: Creating a place for parents on the school landscape. Alberta Journal of Educational Research, 50(3), 221-235. https://journalhosting.ucalgary.ca/index.php/ajer/article/view/55086

Rahman, K. (2013). Belonging and learning to belong in school: The implications of the hidden curriculum for Indigenous students. Discourse: Studies in the Cultural Politics of Education, 34(5), 660-672. https://doi.org/10.1080/01596306.2013.728362

Resta, P., \& Laferrière, T. (2015). Digital equity and intercultural education. Education and Information Technologies, 20(4), 743-756. https://doi.org/10.1007/s10639-015-9419-z

Richards, J. G., Vining, A. R., \& Weimer, D. L. (2010). Aboriginal performance on standardized tests: Evidence and analysis from provincial schools in British Columbia. Policy Studies Journal, 38(1), 47-67. https://doi.org/10.1111/j.1541-0072.2009.00344.x 
Riley, T., \& Pidgeon, M. (2019). Australian teachers voice their perceptions of the influences of stereotypes, mindsets and school structure on teachers' expectations of Indigenous students. Teaching Education, 3O(2), 123-144. https://doi.org/10.1080/ $\underline{10476210.2018 .1453796}$

Ruimy, D. (2017). Broadband connectivity in rural Canada: Overcoming the digital divide. Report of the Standing Committee on Industry, Science and Technology. House of Commons. https://www.ourcommons.ca/Content/Committee/421/INDU/Reports/RP9711342/indurp 11/indurp11-e.pdf

Schick, C. (2014). White resentment in settler society. Race Ethnicity and Education, 17(1), 88-102. https://doi.org/10.1080/13613324.2012.733688

Simpson, L. B. (2014). Land as pedagogy: Nishnaabeg intelligence and rebellious transformation. Decolonization: Indigeneity, Education, \& Society, 3(3). https://jps.library.utoronto.ca/ index.php/des/article/view/22170

Statistics Canada. (2016). Aboriginal Peoples in Canada: First Nations people, Métis, and Inuit (Catalogue no. 99-011-X2011001). https://www12.statcan.gc.ca/nhs-enm/2011/as-sa/99011-x/99-011-x2011001-eng.cfm

St. Denis, V. (2007). Aboriginal education and anti-racist education: Building alliances across cultural and racial identity. Canadian Journal of Education/Revue canadienne de l'éducation, 30(4), 1068-1092. https://doi.org/10.2307/20466679

Steeves, L. E., Carr-Stewart, S., \& Marshall, J. (2010). Aboriginal student educational attainment: A Saskatchewan perspective. EAFJournal, 21(2), 19-34.

Subhan, F., Williams, K., \& Chan, C. (2020). Barriers and mitigating strategies to healthcare access in Indigenous communities of Canada: A narrative review. Healthcare, $8(2)$. https://doi.org/ $\underline{10.3390 / \text { healthcare } 8020112}$

Szabo, T., Richling, S., Embry, D. D., Biglan, A., \& Wilson, K. G. (2020). From helpless to hero: Promoting values-based behavior and positive family interaction in the midst of COVID- 19. Behavior Analysis in Practice. Advance online publication. https://doi.org/10.1007\%2Fs40617$\underline{020-00431-0}$

Thorne, C. M. (2017). Alternative education on Prince Edward Island: A hybrid of "mainstream” and special education. Emotional and Behavioural Difficulties, 22(4), 365-382. https://doi.org/ $\underline{10.1080 / 13632752.2017 .1308713}$

Toulouse, P. R. (2013). Beyond shadows: First Nations, Métis and Inuit student success (ED586058). Eric Database. https://files.eric.ed.gov/fulltext/ED586058.pdf

Truth and Reconciliation Commission of Canada (TRC). (2015a). Calls to action. Portage and Main Press. http://trc.ca/assets/pdf/Calls to_Action_English2.pdf 
Cherubini: Education in the Post-Pandemic Era

Truth and Reconciliation Commission of Canada (TRC). (2015b). Honouring the truth, reconciling for the future: Summary of the final report of the Truth and Reconciliation Commission of Canada. http://nctr.ca/assets/reports/Final\%20Reports/Executive_Summary_English_ Web.pdf

Viner, R. M., Russell, S. J., Croker, H., Packer, J., Ward, J., Stansfield, C., Mytton, O., Bonell, R., \& Booy, R. (2020). School closure and management practices during coronavirus outbreaks including COVID-19: A rapid systematic review. The Lancet Child \& Adolescent Health, 4(5), 397-404. https://doi.org/10.1016/S2352-4642(20)30095-X

Walter, M. M. (2009). An economy of poverty? Power and the domain of Aboriginality. International Journal of Critical Indigenous Studies, 2(1), 2-14. https://doi.org/10.5204/ijcis.v2i1.32

Watego, L. (2005). An Indigenous perspective on mathematics contextualisation in a pre-school: From safety to empowerment. In D. Gronn, M. Horne, A. Roche, R. Pierce, A. Downton, \& P. Clarkson (Eds.), Building connections: Research, theory and practice-MERGA 28-2005: Proceedings of the annual conference (pp. 767-774). MERGA.

Winzer, M. (1997). Disability and society before the 18th century: Dread and despair. In L. J. Davis (Ed.), The disability studies reader (pp. 75-109). Routledge. 